\title{
Cum se traduce 'rușinea'. Abordare traductologică (I)
}

\author{
Magda Jeanrenaud* \\ Facultatea de Litere, Universitatea „Alexandru Ioan Cuza”, Bd. Carol I 11, 700506 Iași, România
}

\begin{abstract}
Despre articol
Istoric:

Primit 11 decembrie 2016

Acceptat 9 ianuarie 2017

Publicat 23 martie 2017

Cuvinte-cheie:

traducere

semantica 'rușinii'

traducerea conceptelor

neologizare

text specializat
\end{abstract}

\begin{abstract}
Rezumat
Pornind de la sfera semantică și lexicală a conceptelor honte (limba franceză) și, respectiv, rușine (limba română), îmi propun să examinez modul cum se traduce acesta în limba română pornind de la un studiu de caz. În acest scop, voi încerca să elaborez un studiu traductologic comparativ al lucrării lui Boris Cyrulnik, intitulată Mourir de dire. La honte (Éditions Odile Jacob, Paris, 2010) și a traducerii sale în limba română, intitulată Mai bine mor decît să spun. Rușinea (traducere din limba franceză de Valentin Protopopescu, Editura Trei, col. „Psihologia pentru toți”, București, 2012). Textul lui Cyrulnik are o particularitate: oscilează între factura literară şi cea a unui text specializat. Din acest punct de vedere, transpunerea lui pune la încercare teoriile funcționaliste ale traducerii și, mai ales, teoria skopos-ului elaborată de Katharina Reiss și Hans Vermeer: este interesant de analizat cum „decodează” traducătorul „intenționalitatea” acestui tip de text, totuși specializat, cum decide el să transpună sfera sa semantică și lexicală în limba română.
\end{abstract}

\section{1. În loc de introducere}

Primilor traducători români de la începutul secolului al XIX-lea le lipsea instictul limbii, fapt explicabil nu doar prin lipsa unor predecesori, dar și prin aceea că însăși limba literară română abia intra în procesul de fixare: fenomenul este, desigur, prezent în toate culturile, cînd limba începe să fie normată. Spre sfirșitul secolului, cum observa, între alții, Pompiliu Eliade, lexicul limbii dezvoltase suficiente resurse atunci cînd „era vorba de lucruri concrete și de uz curent”, însă „pentru a exprima idei abstracte, era uneori necesar să fie împrumutați termeni din franceză” (Eliade, 2000, p. 291). Și alți erudiți constataseră anterior aceste carențe: Ion Heliade-Rădulescu, de pildă, observase deja că limba română manifesta o considerabilă rigiditate mai ales în „traducerea unor lucrări încărcate de filozofie” (Popovici, 1977, p. 156), de unde și proiectul său, de inspirație educativă și normativă, vizînd alcătuirea un lexic de neologisme care să includă o întreagă serie de termeni pe care el considera că limba are a și-i însuși, sublinia el, „mai ales în științe” (Popovici, 1977, p. 178). Lipsa unui inventar suficient de bogat în termeni noționali le-a apărut multora ca o insuficiență a limbii române din acea epocă. Fenomenul a fost confirmat și de Paul Cornea, care constata, și el, sărăcia terminologiilor necesare traducerii lucrărilor cu caracter științific (Cornea, 1972, p. 97).

Se pare că fenomenul acesta nu a fost doar unul ce s-a manifestat pe termen scurt, ci s-ar fi prelungit şi în perioada interbelică, iar după unii, chiar și mai departe, intrînd astfel într-un fel de proces de ,instituționalizare”. Unele voci l-au explicat prin fragmentarea unei societăți ce suferea de o intensă polarizare, din cauza inexistenței unei clase de mijloc foarte clar configurată. Cel puțin așa sugerează, de pildă, D. Popovici, întrebîndu-se cum se explica o fragmentare socială atît de puternică în vremea lui Ion HeliadeRădulescu, dar și, mai ales, dezinteresul pentru proiectul de bibliotecă universală al acestuia, ce ar fi trebuit să dea un imbold unei activități extinse și sistematice de traducere. Or, arată el, indiferența de care s-a lovit acel program s-ar fi explicat prin faptul că „mulți dintre cei ce ar fi putut susține eforturile lui Heliade, se dispensau bucuros de orice traducere, fiind în măsură să se adreseze direct originalului” (Popovici, 1977,

*Adresă de corespondență: mjeanrenaud@hotmail.com. 
p. 205). Alte voci susțin, în registru mai dramatic, că această configurație a societății românești ar fi constituit „nenorocul României din perioada interbelică”, în măsura în care, în timp ce „elita culturală română și-a păzit cu mult orgoliu cultura ei elitară”, cititorul „popular” nu a avut acces, în traducere, decît la o „literatură industrială” (Cleynen-Serghiev, 2003, p. 71) ${ }^{1}$. Dacă ne raportăm la binecunoscuta schemă a lui Robert Escarpit, putem afirma că „circuitul savant” din spațiul românesc s-a configurat exclusiv prin „difuzarea operelor franceze în limba de origine”, în timp ce cererea în materie de traduceri s-a limitat doar la „circuitul popular” (Cleynen-Serghiev, 2003, p. 54).

Dacă mai facem un salt peste timp, putem constata că lipsa de corență a unui lexic noțional bine structurat continua să fie invocată și la sfîrșitul secolului al XX-lea: deși în anii 1970-1980 programele unor mari edituri precum Meridiane, Univers sau Minerva se lansaseră cu succes în „cea mai spectaculoasă acțiune [...], cea a traducerii de exegeză literară și estetică”2 ${ }^{2}$, Gelu Ionescu remarca și el o „nevoie încă azi foarte viu resimțită” (Ionescu, 1981, p. 33) de a-l îmbogăți și rafina.

Este și motivul care m-a îndemnat să urmăresc azi, la început de secol XXI, care este comportamentul traducătorilor, cei care joacă un rol departe de a fi neglijabil în privința transcodării terminologiilor specializate, a conceptelor, și a structurării lor în limba română. Pentru aceasta mi-am propus să examinez modul în care este tradus conceptul ruşine, precum și lexicul ce se construiește în jurul acestuia, pentru a urmări atitudinea traducătorului față de termenii specializați dintr-o lucrare specializată ce îl aşează chiar în titlu. Este vorba de cartea cunoscutului psihiatru și psihanalist francez Boris Cyrulnik, cel care a introdus în Franța conceptul reziliență, carte intitulată Mourir de dire. La Honte, și publicată în 2010, la Paris, de editura Odile Jacob. Versiunea românească, semnată de Valentin Protopopescu, a apărut la scurt timp, în 2012, la Editura Trei, editură specializată în publicarea unor lucrări de psihologie, psihanaliză, psihoterapie etc.

Cartea este un discurs despre rușinea văzută ca manifestare a unei traume puternice, o afecțiune gravă, pe care terapeutul, psiholog, psihiatru sau psihanalist, care scrie acest discurs, se străduie să o vindece. De la bun început, discursul despre ruşine se dovedește însă a fi unul dificil de articulat, în măsura în care ruşinea nu se lasă spusă, tăcerea fiind, de fapt, o componentă a acestei traume, iar rolul terapeutului, în cazul nostru al naratorului, este să o determine să se exprime în cuvinte; în plus, naratorul nostru nu este un subiect distanțat, cel care asumă îndeobște un discurs de factură științifică, ci, pe alocuri, se metamorfozează la rîndul său într-un subiect afectat de această traumă. Avem astfel de-a face cu un discurs despre rușine asumat de un subiect care vorbește în numele celor rușinați pentru că aceștia nu pot vorbi: rușinea refuză să se lase enunțată. Pentru acest tip de text, transpunerea în traducere a cîmpului semantic al noțiunii centrale ruşine nu are a pune în principiu probleme, neexistînd riscul diseminării sensurilor respectivului concept în rețele polisemice și izotopice, deoarece el este dublu delimitat, la nivel micro-textual, de context şi, la nivel macro-textual, de însuși tipul de text.

Textul apare ca un fel de du-te-vino: specialistul în neuropsihiatrie vorbește ${ }^{3}$ despre ruşinea celorlalți, iar cînd vorbește despre propria ruşine, nu o poate nici el asuma la persoana întîi și atunci discursul trece la persoana a treia. Teoretician al rezilienței, al modalităţilor de depăşire a unei traume în reconstruirea personalității, autorul constată că există trei factori ce împiedică acest proces. Primii doi, izolarea fizică şi închiderea în non-sensul verbal, acționează conjugat, iar depăşirea lor nu poate avea loc decît prin mijlocirea cuvîntului, prin efortul celui traumatizat de a construi povestirea traumei sale, singura modalitate de a da coerență, de a înzestra cu o ordine, cu un sens faptele întîmplate. Or, al treilea factor, ruşinea, îi blochează pe ceilalți doi, împiedicînd construirea povestirii: ruşinea formează o pereche simetrică cu tăcerea (Cyrulnik, 2013).

Ruşinea apare astfel ca o traumă individuală, însă care capătă formă doar sub privirea celorlalți: mai mult decît (im)pudoarea, care este mai strîns legată de funcționarea eului în societate și implică mai puțin

\footnotetext{
${ }^{1}$ Am asumat traducerea tuturor citatelor din limba franceză.

${ }^{2}$ Cleynen-Serghiev (2003, p. 54). Proiectul Heliade „mai are încă o actualitate - în sensul că el nu a fost în întregime realizat", p. 31, p. 49.

${ }^{3}$ A se vedea și emisiunea radiofonică intitulată „Le théâtre intime de la honte”, France Culture, 30 sept., 2015.
} 
direct refuzul / neputința rostirii, ruşinea rămîne intim legată de dezvoltarea personalităţii, de capacitatea eului de a-i percepe pe ceilalți, dar și de modul în care aceștia îl percep. Pentru că acest sentiment, această emoție „traduce aptitudinea noastră de a percepe lumea mentală a celuilalt”, cu alte cuvinte, de „a percepe mental existența celuilalt” (Cyrulnik, 2010b).

Prin urmare, textul este multistratificat: studiu psihologic şi psihanalitic al unei afecțiuni; încercare de popularizare a unei problematici dificile; dar și paradoxal text al nespusului, rușinea fiind, alături de colorarea pielii, marcată de imposibilitatea, pentru cei traumatizați, de a o rosti. „La honte ne peut pas se dire" (p. 38) afirmă autorul, cu ton constatativ, cu neutralitatea practicianului, și nu cum ni se spune, în transpunere românească, „ruşinea nu poate fi mărturisită” (p. 36): un teribil contrasens se instalează astfel, deoarece problema suferindului este spunerea, rostirea, putința de a-și exprima suferința, distanțat, ca o stare de fapt, ca un prim pas spre vindecare, așa cum și spune textul francez, și nu mărturisirea ei, ca o vină (asumată). Poate că a mărturisi „,sună” mai bine, mai poetic decît banalul a spune, însă alegîndu-l, traducătorul întredeschide concomitent și portița către trădare: menirea clinicianului nu este cea de a se exprimă într-un variat lexic poetizant, ci de a-și face meseria în termenii ei. Ca să nu mai vorbim de faptul ca propoziția trimite, cît se poate de direct, la titlul cărții, ceea ce, versiunea românească, odată ce a trecut în registrul mărturisirii, nu mai poate face.

\section{Ce fel de text: perspectiva traductologică}

Primul gest al traducătorului ar trebui să constea în a-și pune întrebarea legată de ce fel de text are a traduce, pentru a decide genul textual de care aparține acesta și a-l încadra apoi într-o tipologie. Însă aceste încadrări nu au nici o relevanță dacă sînt făcute înafara raportării la o tipologie a textelor de tradus: o tipologie care să nu aibă în vedere clasificările tradiției literare, ci să opereze ierarhizări strict legate de modurile de a traduce. Nu de mult timp, teoriile traducerii, ca și critica și evaluarea acestora, acordă tot mai multă atenție tipului textului de tradus și a intenționalității pe care o exprimă el, elemente determinante în luarea deciziilor privind tehnicile de traducere. Una dintre cele mai flexibile teorii funcționaliste ale traducerii, teorii ce au jucat un rol considerabil și în detensionarea binomului fidelitate / trădare în actul traducerii, este așanumita teorie a skopos-ului, poate nu întîmplător elaborată în spațiul german, dacă ținem cont de faptul că în cultura germană asocierea traducerii cu trădarea a fost mult mai sporadică decît în limbile și culturile romanice, sfera semantică a conceptului de traducere construindu-se, prin intermediul traducerii Bibliei de către Martin Luther, în jurul ideii de transmitere, transplantare, și mai puțin de infidelitate.

Deși împărțite, opiniile privind specificitatea textului filozofic și, mai general, a discursului științelor umane, ca necesitînd tehnici și decizii traductologice distincte, sînt însă consensuale cînd vine vorba de necesitatea depăşirii binarismului tradițional ce împarte textele de tradus în două categorii, cea a textelor pragmatice și cea a textelor literare, dicotomie care a valorizat dintotdeauna traducerea literară și a depreciat traducerea specializată, văzută adesea mai degrabă ca un mecanism rigid de transpunere a unor inventare terminologice dintr-o limbă în alta. Pornind de la schema lui Karl Bühler, dar și de la conceptul jakobsonian de dominantă, Katharina Reiss (2002, p. 30-60) a pus la punct o foarte elastică tipologie centrată pe predominanța unei funcții sau alteia a limbajului, ce diferențiază trei categorii de texte de tradus. Textele incitative, unde funcția de apel este preponderentă, trebuie traduse ținînd cont de prezența intensă a respectivei funcții: prin urmare, ele ar trebui transpuse în funcție de intenționalitatea lor, apelîndu-se la o întreagă gamă de procedee capabile să producă asupra receptorului un efect de natură extralingvistică, declanșinnd o reacție dinainte determinată. Textele expresive, care solicită într-un înalt grad funcția expresivă a limbii, ar trebui transpuse din perspectiva formei lor, pentru că specificitatea lor decurge din modul cum sînt utilizate procedeele stilistice, estetice, semantice și gramaticale. În fine, categoria textelor informative se remarcă prin predominanța funcției reprezentative: de ea trebuie să țină cont în primul rînd traducătorul, atenția lui concentrîndu-se în principal pe transmiterea adecvată a conținutului, configurația formală trecînd oarecum în planul al doilea. Textele așa-numite specializate se încadrează în categoria textelor informative întrucît scopul lor principal constă în transmiterea cu precădere a conținutului, pe 
care traducătorul are a-l reda în integralitate, urmărind obținerea invarianței în planul conținutului (Reiss, 2002, p. 56). După cum se poate vedea, o astfel de tipologie, centrată pe criteriul funcției dominante a textului de tradus tinde să gestioneze și tensiunile legate de dramatica certitudine a teoriei, dar și a multor traducători, privind inevitabilele pierderi ce se produc în orice proces de traducere, atunci cînd acesta este văzut ca un parcurs ce urmărește reproducerea integrală a originalului: este astfel consolidată, inclusiv la nivel teoretic, posibilitatea limitării „pierderilor” sau, în orice caz, a catalogării lor drept secundare, acceptabile, odată ce scopul traducerii devine producerea unui text țintă echivalent (celebra echivalență fără identitate a lui Paul Ricœur) (Ricœur, 2005, p. 90), unde reușita este strîns legată de reconstruirea funcției dominante a textului sursă. Transpunerea funcției dominante a textului sursă, cu alte cuvinte a skopos-ului acestuia, corect descifrat de traducător pentru a aplica apoi strategiile de traducere adecvate lui, are drept consecință, pe de o parte, consolidarea poziției receptorului, iar pe de alta, deplasarea în plan secundar a binomului fidelitate / trădare: din această perspectivă, fidelitatea nu mai asociază cele două texte în virtutea unei filiații directe, iar trădarea se diluează, în măsura în care capătă implicit o legitimitate și este preluată de o sumă de tehnici de traducere ce nu mai impun conformitatea absolută dintre ele.

Lucrarea de care ne ocupăm poate fi încadrată fără ezitare în categoria denumită de Reiss a textelor cu dominantă informativă (Reiss, 2002, p. 44), alături de disertații, eseuri, monografii, lucrări cu caracter didactic, tratate, reportaje, comentarii de presă, într-un cuvînt, în categoria textelor aparținînd de științele umane. Elementul pe care-l au ele în comun din punctul de vedere al strategiilor traductive este dominanta, cu alte cuvinte transmiterea unui conţinut, însă cu grija de a nu cădea în capcana unei „concepții pur funcționaliste asupra limbii”, pierzînd din vedere faptul că „modalitatea în care este exprimată o idee contează cu nimic mai puțin decît ceea ce se este spus” (p. 45). Dar maniera în care un autor recurge la un mijloc expresiv sau altul este în acest caz subordonată transmiterii unui conținut. Traducătorul va produce o traducere reușită doar în măsura în care va găsi calea de a transpune integral conţinutul cognitiv, altfel spus tema și argumentul (p. 46), „semantica, gramatica și stilistica” acestuia (p. 45).

Înafară de prezența terminologiei specializate, manifestă în proporții variabile de la un gen la altul, textele informative cu intenții de popularizare și/sau de factură eseistică, cu ambiții literare, se remarcă prin „rigoarea expunerii, exactitatea informațiilor transmise și prin aceea că sînt scrise într-o limbă uzuală” (Reiss, 2002, p. 47). Lucrarea lui Boris Cyrulnik este adresată unui public larg, poate și de profani, ceea ce ar implica o „atenție sporită din partea traducătorului pentru instrucțiunile de ordin stilistic” (p. 47): deîndată ce am ,identificat textul ca pe unul informativ, dispunem de o primă instrucțiune, care este decisivă” (p. 47) și care determină alegerea modului de traducere. Traducătorul trebuie să își fixeze aşadar drept sarcină prioritară obținerea ,invarianței în planul conținutului” și să o realizeze recurgînd nu doar la o limbă corectă, ci și uzuală (p. 48), cu atît mai mult cu cît textul în discuție se dezvoltă pe o structură dublu stratificată, unde se poate deosebi cu ușurință narațiunea, produsul unui narator ce se asumă ca personaj, de argumentarea, în registru impersonal, a unei tematici de factură teoretică.

\section{Titlul și traducerile sale}

Pornind de la aceste elemente putem schița o analiză a modului cum a fost redat titlul și apoi a modului cum au fost transpuse rețelele ce alcătuiesc cîmpul lexical al rușinii în acest text. Cartea a fost tradusă în limbile germană, spaniolă și română. Relația improbabilă între un discurs-prin esența sa spuneredespre ceva-ruşinea - care, tot prin esența sa, refuză spunerea, se reflectă și în diversele decizii privind traducerea titlului. Titlul orginal, Mourir de dire. La honte, este probabil inspirat dintr-un studiu semnat de psihanalista Rachel Rosenblum, intitulat însă, interogativ, „Peut-on mourir de dire?” (Rosenblum, 2000, apud Cyrulnik, 2010a. Cf. Rosenblum, 2000, p. 113-138), formulă clarificată de autoare încă de la începutul rezumatului, însă tot printr-o întrebare: „Peut-on mourir d'écrire la catastrophe?” Marile catastrofe, spune dînsa, au ceva în comun: nespusul, un nespus care poate duce la tăcerea definitivă, la moarte. Însă, se mai întreabă autoarea, scrierea, rostirea, divulgarea unei traume nu este oare tot o „decizie cu consecințe grave”? Nu se poate muri din cauza unei spuneri? Mari scriitori precum Sarah Kofman 
sau Primo Levi au dat un răspuns acestei întrebări. Și nu altfel a răspuns, la un nivel și mai dramatic, un Paul Celan, cel ce găsise mereu „cuvintele potrivite și încă în limba asasinilor” (Rosenblum, 2000, p. 115), iar Jorge Semprun a formulat fără drept de apel imposibilitatea unei ieșiri din alternativa a trăi / a scrie (Semprun, 1994).

Am făcut această paranteză pentru a sugera că dificultatea traducerii unui titlu care asociază verbele $a$ spune și a muri cu ruşinea nu trebuie defel tratată cu ușurință. Titlul francez alătură două infinitive, adică, cum spune dicționarul Larousse, două „forme nominale a căror funcție esențială este de a enunța pur și simplu procesul exprimat de verb": ca atare ele sînt impersonale și atemporale, abstracțiuni ce exprimă ideea unei acțiuni sau stări. Din acest punct de vedere, varianta românească, Mai bine mor decît să spun, dincolo de tonul ei jucăuș, săltăreț, care împinge formula într-un registru cu totul diferit de cel al textului ce îi urmează, deschide larg și porțile unui teribil contrasens: aici avem de-a face cu un subiect ce-și proclamă, într-o formulare personală, sprintenă, parcă voioasă, pentru că amintește de sonoritățile cîntecelor de joacă ale copiilor-șase cuvinte scurte, alternînd monosilabismul cu bisilabismul—, capacitatea de a păstra un secret, dorinţa de a nu vorbi, într-o formulare comparativă. Iar asocierea cu partea a doua a titlului, ruşinea, se citește astfel ca o promisiune, un angajament de a tăcea, a cărei transgresare ar putea aduce moartea. Ceea ce nu este totuna cu semantica titlului original, ci recurge la o construcție menită să atragă atenția, ca atîtea altele ce folosesc un limbaj, să spunem, de tip mediatic. Propoziția circumstanțială comparativă de inegalitate de tipul mai bine... decît sau decît... mai bine exprimă o opoziție prin intermediul unei comparații (Graur, 1973; Crașoveanu, 2002, p. 65-66): ea așează în comparație două fapte contrarii, ceea ce nu este defel intenția textului original, dar și opacifiază trimiterea, care devine contradictorie, către termenul ruşine, ce completează, în franceză, primul segment, singularizînd, precizînd situația impersonală exprimată de acesta. Ruşinea apare astfel ca un fel de sancționare a rostirii, contrazicînd întreg conținutul cărții ce urmează după titlul Mai bine mor decît să spun. Ruşinea.

În limba germană titlul a fost transpus prin Scham. Im Bann des Schweigens - Wenn die Seele vergiftet (Cyrulnik, 2011a), titlu ce forțează masiv explicitarea termenului cheie rușine, care în franceză era așezat la sfîrșit, pentru a preciza generalitatea lui „mourir de dire”. Cîmpul lexical al ruşinii, în care iese în relief tăcerea, este extins la „otravă a sufletului”, formulă, este adevărat, recurentă în textul original, trăsăturile esențiale ale noțiunii ruşine fiind practic de la bun început delimitate prin inversarea traseului generalparticular pe care era construit titlul original.

În spaniolă, cartea a fost tradusă sub titlul Morirse de vergüenza. El miedo a la mirada del otro (Cyrulnik, 2011b) (teama de privirea celuilalt). Titlul spaniol particularizează și el tema ruşinii, însă recurge la o expresie paroxistică, ,a muri de rușine”, pe care o determină printr-un subtitlu ce o explicitează, îndepărtîndu-se mult de titlul original, pentru că nu mai trimite la impactul tăcerii ce distruge eul, ci situează originea traumei nu în nespus, ci în privirea celuilalt.

Termenul spaniol vergüenza a evoluat altfel decît vergogne, în franceză, care este astăzi considerat un termen arhaizant și literar, el rămînînd activ doar în expresia sans vergogne, fără rușine. Fiind asociat mereu cu un „marcator de negativitate”, termenul a sfîrșit prin a trimite la „o dezaprobare binevoitoare vecină cu ironia”, subiectul calificat astfel vădind în special o „lipsă de scrupule și de reținere” (Cassin, 2004, p. 1338), căreia i se poate asocia o „conotație imorală”, în timp ce, în spaniolă, „motivul rușinii [...] ține de sperjur, de violarea unui angajament care aduce atingere demnității” (un hombre con vergüenza), și, în consecință, legătura cu socialul, raportul cu colectivitatea se situează în centrul sferei sale semantice: ca și în limba italiană, în spaniolă, termenul întreține astfel o strînsă legătură cu stima de sine și cu un sentiment colectiv (vergüenza ajena, în traducere literală, ruşinea provocată de comportamentul celorlalți, în franceză, la vergogne de l'autre) (Cassin, 2004, p. 1339). Ca atare, absența sa totală din versiunea franceză demonstrează că el nu poate dezvolta nici o legătura cu sfera psihologică specializată a cărții, fapt ce vine să confirme dominanta acestui tip de text și constituie un semnal în plus pentru traducătorul atent, care ar trebui să urmărească cu precădere în traducerea sa ,invarianța conținutului”, fără a ceda tentațiilor poetizante.

Cît despre un eventual titlu în limba engleză (limbă în care cartea nu s-a tradus încă după știința mea), versiunea engleză a site-ului editurii Odile Jacob prezintă cartea sub titlul Telling and dying of shame: 
Magda Jeanrenaud

formularea aceasta, care coordonează într-una și aceeași structură spunerea și sancțiunea nespunerii, mi se pare a fi și cea mai apropiată de titlul original.

\section{Coerența titlului: rolul său în construirea izotopiei principale a textului}

Cum se întîmplă adesea, titlul este reluat în oglindă în corpul textului, iar această reflectare repetitivă, pe lîngă funcția sa „didactică”, are și menirea de a susține coerența întregului: astfel de redundanțe, niciodată întîmplătoare, contribuie la consolidarea armăturii textuale, creează și alimentează rețelele de sens și, nu de puține ori, însăși simbolica unui text.

Explicarea titlului și inclusiv trimiterea la textul semnat de Rachel Rosenblum ne este dată chiar de la pagina a doua a cărții: „Il croit qu'il va mourir de dire” (p. 8) spune autorul, iar traducătorul român transpune în „El este încredințat că va muri dacă nu o să vorbească” (p. 8) acolo unde, de pildă, versiunea spaniolă reia segmentul din titlu: „Cree que se morirá de vergüenza”. Același segment reapare în textul original, din nou cu trimitere la textul lui Rachel Rosenblum (p. 84), pentru a scoate în evidență complexitatea interacțiunii dintre două povestiri, cea a eului despre sine și cea pe care ceilalți o construiesc despre acesta. Aceasta din urmă poate uneori să destabilizeze eul, adîncindu-i rănile: „Dans une telle enveloppe verbale, on peut très bien «mourir de dire» et souffrir de ne pas dire”. În română, citim însă că „ Întrun asemenea înveliş verbal se poate foarte uşor «muri pentru o vorbă » și suferi pentru că nu am spus-o" (p. 78): comprehensiunea este perturbată nu doar de trecerea de la modul impersonal la unul personal, ci și de distrugerea coerenței vizavi de titlu, ca să nu mai vorbim, iarași, de frivolitatea poetizantă a lui „a muri pentru o vorbă”, care este extrem de departe de exprimarea traumei, de putința rostirii ei.

\section{Despre semantica ruşinii}

Fără doar și poate că rușinea, care paralizează, în cazul traumelor adînci (și nu doar) capacitatea transpunerii lor în cuvinte, nu se lasă lesne tradusă. Am văzut cîte măsuri de prevedere și-au luat traducătorii în cazul titlului, versiunea germană remarcîndu-se printr-o excesivă explicitare a cîmpului semantic al ruşinii. Faptul are, poate, o dublă explicație, una ce ține de evoluția termenului în lexicul uzual al limbii germane, și cealaltă de particularitățile elaborării semnificației sale specializate în cadrul psihanalizei și, mai ales, al lexicului freudian.

Într-un studiu de mari dimensiuni dedicat „teoriei psihanalitice a rușinii”, unde pornește de la diferențierea a două niveluri de sens în interiorul conceptului ruşine, unul referindu-se la sfera intimității, ce trimite la ruşinea propriu-zisă, și celălalt la sfera socială, adică la pudoare, Claude Janin (2003) cita, întro secțiune consacrată semanticii ruşinii și traducerii acesteia în engleză și franceză în cazul Gesammelte

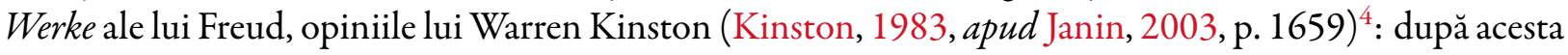
din urmă, cele două niveluri sînt mai puțin diferențiate în cazul limbii engleze, care denumește ruşinea și pudoarea cu un singur termen, shame, în timp ce franceza și germana, la care am adăuga și cazul limbii române, dispun de doi termeni.

Distincțiile operate atît de celebrul glosar francez (Bourguignon et al., 1989, apud Janin, 2003) elaborat în vederea traducerii operelor complete ale lui Freud, cît și de tabelele de corespondență ale Standard Edition engleze, dar și de traducători, între echivalențele lui Scham și Schande sînt ezitante ${ }^{5}$, ceea ce scoate din nou în evidență variația cîmpurilor semantice de la germană la engleză. Autorii francezi consideră că Schande corespunde pudorii, dar că poate avea și sensul de ruşine; însă toți constată că ambii termeni se intersectează uneori, în măsura în care intimul, sexualitatea și socialul sînt dificil de separat. Ocurențele termenului Schande din Micul Hans, de pildă, au fost traduse în versiunea românească tot prin termenul ruşine (Freud, 2010b, p. 11-141; Freud, 1909), ceea ce întărește ideea amestecului dintre sfera intimă

\footnotetext{
${ }^{4}$ Kinston stabilea de altfel echivalența între Scham și pudoare și, respectiv, Schande și ruşine, pe baza derivatului german Blutschande pentru incest.

590 de ocurențe ale lui shame corespund celor 42 din textul german (Janin, 2003, p. 1658).
} 
și cea socială în cazul celor doi termeni: cînd Schande trimite la contexte cu conotaţii sexuale, atunci transpunerea s-a făcut constant prin ruşine / honte (Freud, 2010a) ${ }^{6}$, iar în Traumdeutung, de pildă, unde există, dacă nu mă înșel, o singură ocurență a lui Schande (în cap. V) legată de sexualitate, ea a fost transpusă tot prin ruşine.

Scham se asociază astfel cu pudoarea, prin legătura cu anatomicul, dar și cu suferinţa provocată de dezvăluirea a ceva ce ar trebui să rămînă tăinuit. Janin compară diverse definiții de dicționar ale termenului francez honte, de unde reiese că distincția dintre intim și social, dintre caracterul psihic și cel social al rușinii, nu este la fel de tranșantă ca în germană, dar și imposibilitatea de a trasa o linie clară de demarcație între ruşine și pudoare. Pe de altă parte, mai spune Janin, lipsa unei teorii a ruşinii în opera lui Freud a avut consecințe asupra evoluțiilor teoretice ulterioare dar și, cred eu, cum vom vedea, asupra traducerii lexicului ruşinii. Poate că astfel se poate explica amplificarea considerabilă a titlului german, unde Scham, devenit cuvint-pivot al titlului, este dublu determinat prin Im Bann des Schweigens - Wenn die Seele vergiftet.

În majoritatea dicționarelor, atît franceze, cît și românești, rușinea și pudoarea sînt considerate a fi sinonime. Pe site-ul Centre National des Ressources Textuelles et Lexicales, sînt enumerate 46 de sinonime pentru honte, iar pudeur figurează pe locul 5 ca frecvență, în vreme ce, la rubrica antonime, alcătuită din 8 termeni, toți înregistrați cu o frecvență egală, impudeur ocupă locul 6. Printre sinonimele lui pudeur, honte ocupă locul 6, cu o frecvență mult mai redusă decît, de exemplu, retenue, réserve, décence. DEX-ul românesc asociază rușinii următoarele sensuri: 1. Sfială, jenă provocată de un insucces sau greșeală; 2. Rezervă, modestie, sfială; 3. Ofensă; 4. Dezonoare, umilință, înjosire; 5. Denumire a organelor genitale. Pudoarea este definită ca: 1 . Sfială, jenă, decență și, în limbaj juridic, cu referire la sexualitate, în expresia atentat la pudoare.

Într-un text de factură specializată, cu temă psihologică și psihanalitică, la honte trebuie așadar redată în toată concretitudinea ei, prin ruşine, adică prin termenul capabil să exprime o traumă, și nu prin pudoare, adică o rușine sfielnică, discretă și rezervată. În limba română, substantivul ruşine nu dispune de un antonim construit pe baza prefixului ne-sau im-, în timp ce pudoarea posedă antonimul impudoare: în franceză, de unde s-a și împrumutat termenul românesc pudoare, la honte (ruşinea) are drept antonim, printre altele, tocmai termenul... impudeur. Tot ce se poate ca însăși etimologia românească a ruşinii, legată de latinescul roseus, care trimite, concret, la culoarea roșie, să determine o legătură mai strînsă cu perceptibilul în cazul termenului românesc: manifestarea fiziologică, palpabilă, a ruşinii este, la nivelul întregii specii umane, înroșirea pielii obrazului, însă în cazul limbii române, ea este astfel inclusă, înglobată în sfera sa semantică. Mai rămîne însă și ca lexicul acesteia, cîmpul lexical ce o înconjoară, să păstreze, într-o traducere, coerența vizavi de termenul cheie.

\section{Ruşinea se poate cuantifica}

În comparație cu pudoarea, ruşinea este așadar „măsurabilă”, are o „greutate” în sensul aproape propriu al termenului: tocmai pentru că ruşinea trimite, atît în franceză, cît și în română, la ceva concret, un subcapitol poartă titlul Peut-on chiffrer la honte? (p. 91-94) // Putem să cuantificăm ruşinea? (p. 83-86): ruşinea se poate „cuantifica”, într-o măsură mult mai mare decît pudoarea, după cum o dovedește funcționarea morfo-sintactică a celor doi termeni. Ruşinea poate fi mică sau mare, ea poate apăsa prin greutatea sa sau poate fi uşoară (nu spunem oare industrie uşoară, dar și o boală uşoară, tot aşa cum moravurile pot fi, și ele, uşoare?). Traducătorul variază însă mult mai mult decît i-o sugerează textul original (iar în cazul de față variația conotează o ezitare): el preferă, în plus, termeni cu potențial polisemic, ceea ce subminează implicit traseul denotativ. Astfel, la petite honte este cînd mărunta ruşine, cînd o uşoară senzație de ruşine, cînd un uşor sentiment de ruşine, iar grande honte devine marea ruşine, dar și o ruşine amplificată. Cît despre le moindre sentiment de honte, unde moindre se referă la o noțiune abstractă, dar de cele mai multe

${ }^{6} \mathrm{Cu}$ precădere cap. V, Materialul și sursele visului (cf. Freud, 1900, cap. V, Das Traummaterial und die Traumquellen („Pfui, das ist eine Schande, das darf man nicht” [Pfui, e rușine, nu e voie]). 
ori cuantificabilă, el este redat prin mărunt, care nu acceptă cuantificarea și al cărui sens figurat vine să tulbure claritatea textului original.

Chiar la începutul cărții, putem citi, în subcapitolul intitulat Transparence du honteux (Transparența celui care suferă de ruşine), că la honte lui tombe en pleine tête (p. 33), iar traducătorul redă în toată amploarea ei lovitura fizică în ruşinea îl izbeşte frontal (p. 32): instrucțiunile intra-lingvistice ale textului-sursă sînt clare și ele trebuiau doar urmate consecvent pe toată durata textului. În franceză, la honte are, în sens foarte concret, o greutate, un poids, care, din nou, se diluează pînă la contrasens în apăsarea ruşinii, pentru că deturnează o însușire, proiectînd-o în senzație a unui subiect, deoarece numai el poate fi apăsat de rușine. $\mathrm{Nu}$ altfel se petrec lucrurile în cazul construcției la honte est plus légère (p. 26), transpusă prin rușinea este mai suportabilă (p. 24), unde intervine din nou o instanță exterioară, care decide gradul de suportabilitate al celui afectat de rușine. Seriile grand-petit-moindre-zeste și poids-léger, menite a susține caracterul fizic al unei traume, se diluează în serii aproximative, unde o parte din termeni sînt selectați în virtutea însuşirilor lor poetizante ${ }^{7}$ : un zeste de honte, unde zeste continuă seria însușirilor „cuantificabile”, cum o spune și titlul subcapitolului, este redat printr-o fărîmă, termen posibil de cuantificat, dar cu uz rar, și cu aură poetizantă. Perifraza și preferința pentru sinonime mai degrabă poetice, devin astfel figurile tutelare, alcătuind norma la care se supune traducerea, adică exact opusul proiectului unui textul specializat în general și a acestuia în special.

Un souvenir d'enfance // O amintire din copilărie

Alain... s'est tué... sans jamais avoir éprouvé le moindre sentiment de honte simplement la petite honte

\section{Le détracteur intime // Detractorul intim}

la honte est plus légère

le poids de la honte

c'est ma honte, ma grande honte
Alain... s-a sinucis... fără să fi încercat vreodată cel mai mărunt sentiment de rușine pur și simplu e în discuție doar mărunta ruşine rușinea este mai suportabilă apăsarea rușinii e rușinea mea, marea mea rușine

o uşoară senzaţie de rușine

La honte peut durer deux heures ou vingt ans // Ruşinea poate dura două ore sau două decenii les petites hontes de la vie quotidienne măruntele rușini ale vieții cotidiene un zeste de honte o fărîmă de rușine

Bonheur et pulsions. Honte et morale // Fericire și pulsiuni. Rușine și morală une petite honte une grande honte un uşor sentiment de ruşine o rușine amplificată

\section{Traducerea conceptelor}

Textul se situează, cum spuneam, cumva la jumătatea drumului dintre tratatul specializat și eseu. Textul este și, în același timp, nu este o lucrare de popularizare, în măsura în care autorul este și narator, cu alte

\footnotetext{
${ }^{7}$ De observat și apariția, în trecutul apropiat, a diminutivului ruşinică, folosit la un moment dat de umoriști, cu trimitere peiorativă la diversele abateri ale politicienilor, dar care pare a nu fi intrat totuși în uz.

${ }^{8}$ Pentru fluiditatea lecturii și ținînd cont de dimensiunile reduse ale subcapitolelor, am preferat să grupăm exemplele din tabele pe subcapitole, dîndu-le titlul.
} 
cuvinte, în măsura în care, pe alocuri, „vocea” psihiatrului se amestecă cu cea a „pacientului”, asumînd-o la persoana întîi.

Nu puțini sînt cei ce au văzut în însăși decizia de a traduce discursului științelor umane o „profanare” a intenționalității-transmiterea unor conținuturi universale - unui asemenea tip de text. Jean-René Ladmiral (Ladmiral, 1998, p. 977-994) asimila această decizie cu o atingere adusă însăși Rațiunii: să recurgi la operațiuni ce disociază „semnificații conceptuali ai filozofiei [...] de semnificanții [...] limbii originale, pentru a le asigura ulterior «reîncarnarea » în alți semnificanți, semnificanți străini, ai limbii de sosire sau «limbii-țintă» în care este tradus textul” (Ladmiral, 1989, p. 6) este, pentru traductologul și traducătorul francez, un adevărat „scandal” (Ladmiral, 1989, p. 988) , pentru că textul de factură filozofică are drept scop dezvăluirea unei Rațiuni universalizante fără să știe cum să evite nu doar „particularismul istoric și cultural al tradițiilor naționale”, ci și „accidentele lingvistice, pe drept cuvînt denumite «idiomatice», ale limbilor naturale". Astfel încît, mai mult decît în cazul oricărui alt tip de text, traducerea scoate aici la lumină o teribilă tensiune: „transparența rațională a semnificaților conceptuali spre care tinde discursul filozofic [...] este întunecată de «impurităţile» contingente ale semnificantului lingvistic" (Ladmiral, 1998, p. 983). De aceea și consideră Ladmiral că opozițiile clasice (traducere tehnică versus traducere literară), cît și tipologiile mai complexe, precum cea propusă de Katharina Reiss, nu au o adevărată utilitate metodologică. Alături de traducerea pragmatică, „aplicabilă” textelor axate pe referent, și traducerea literară, a textelor unde predomină funcția expresivă a limbajului, ar fi astfel loc pentru încă o categorie de texte, cea a discursului științelor umane, discurs al cărui referent este propriul semnificat.

Textul de factură filozofică apare astfel ca o structură stratificată (ceea ce alimentează polemicile privind modurile de traducere, unificate sau nu, ale celor două niveluri, al limbajului specializat și al narațiunii): oricum ar sta lucrurile, traducătorului îi revine sarcina de a deosebi limba textului de cuvîntul autorului, adică acel sistem de indicii ce lasă asupra textului amprenta unei subiectivități particulare (Ladmiral, 1994, p. 223).

\section{Reticența față de neologizare: imposibila substantivare}

Substantivarea adjectivului honteux în le honteux pretinde, nu doar în limba franceză, ci și în română, germană și spaniolă, un efort de neologizare, substantivarea adjectivului fiind probabil la fel de acceptabilă în cele patru limbi. Fapt este că, odată ce traducătorii au avut curajul de a o impune, menținînd astfel cu strictețe coerența terminologiei textului original, termenii au fost acceptaţi ca atare, de vreme ce atît der Beschämte (Gehring, 2011), cît și el avergonzado (Almonte, 2011, p. 387-388; Tristán, 2011) sînt folosiți de autorii recenziilor dedicate cărții.

În limba română însă, din cauza reticenței traducătorului, s-a ratat o șansă de îmbogățire a terminologiilor. Aici asistăm la un efort continuu (aș spune chiar trudă) al traducătorului de a numi categoria „celor suferind de rușine” în diverse feluri: el pare că dorește să compenseze astfel propria reticență în a neologiza substantivînd adjectivul rușinos, printr-o întreagă serie de perifraze. Însă scopul textului sursă nu este să dovedească cine știe ce „măiestrie” lexicală, nici să compenseze teama de repetiții, ci să construiască și să definească, ca orice text specializat, o grilă sigură de concepte, printre care un rol central îl ocupă tocmai numirea celui afectat de trauma rușinii.

Limba română ar fi putut oferi două posibilități de substantivare, ambele cu sfere semantice largi, oscilînd între timiditate, sfială, adică înclinînd spre pudoare, și rușinea „propriu-zisă”: pe de o parte „rușinosul”, care pare însă a fi un termen „slab”, în măsura în care conotează mai curînd sfiala, timiditatea, sau „ruşinatul”, prin derivarea prin afixul -at, care trimite la aceleași nuanțe de sens, dar și la „copleșit de rușine”. Decizia este fără doar și poate dificilă, traducătorii se feresc în general de neologizare, care îi expune le diverse critici, însă, în cazul de față esențială este construirea grilei terminologice, iar dispersarea

\footnotetext{
${ }^{9}$ La acest scandal se referea implicit și Paul Ricœur, atunci cînd invoca nedeterminarea definită de Quine, specifică oricărei traduceri, dar care, în cazul textelor filozofice, înzestrate cu o armătură semantică riguroasă, iese în evidență îmbrăcînd forma paradoxului (Ricœur, 2005, p. 70).
} 
în nenumărate perifraze nu o poate în nici un caz servi. Termenul ales ar trebui să conoteze cît mai puțin sfiala, rezerva, pentru că tema lucrării privește cazurile de mari traumatisme de toate felurile, dezrădăcinarea, violul, sărăcia, dar și îmbogățirea excesivă, expulzarea dintr-un grup, supraviețuirea lagărelor etc.: din acest punct de vedere, ar fi preferabil nu substantivul ruşinosul, cel care este și sfios, timid, trăsături de caracter ce nu au nimic a face cu cazuistica aflată în discuție, ci substantivul ruşinatul: cel care este traumatizat și, de cele multe ori, își conștientizează trauma în confruntarea cu celorlalți, copilul foarte murdar care, sub privirile înspăimîntate ale unei femei doritoare să-l găzduiască cîteva zile, conștientizează brusc propria stare, și devine ruşinat, nu, cum spune versiunea românească, de felul cum arăta, ci de propria imagine, așa cum i-o trimitea privirea celuilalt și pe care o percepea pentru prima dată.

\section{La manière d'aimer est un mode de socialisation // Felul in care iubim este o modalitate de socializare l'enfant eut honte de ce qu'il était sous le regard de cette dame copilului i se făcu ruşine de felul cum arăta}

Într-o singură ocurență, aflată la începutul lucrării, traducătorul substantivează, noi, ruşinoşii (p. 12), însă în rest recurge la tot felul de perifraze, încît această unică ocurența apare mai curînd ca o „neglijență”, corectată apoi de-a lungul întregului text. În aceeași frază, apare și antonimul lui les honteux, l'éhonté, iar traducătorul ratează din nou grila, deși ar fi putut folosi derivarea, existentă în limba română, neruşinat: el preferă însă să vorbească de un neobrăzat, termen ce trimite, din nou prin contrasens, la obrăznicie, impertinență, necuviințăă, acolo unde era vorba pur și simplu de lipsa ruşinii celui care, divorțind de o soție ce se va sinucide, nu resimte nici un sentiment de vinovăție: desigur că nu neobrăzarea este, în acest caz, defectul personajului, ci incapacitatea de a simţi ruşinea. Dacă nu mă înșel este și singura ocurență a lui éhonté: autorul pare că înclină, în alcătuirea grilei sale conceptuale, spre un surplus de transparență și, spre sfîrșitul lucrării, intitulează un subcapitol Les sans-honte (p. 236-243), unde creează un substantiv compus pe baza structurii adverbiale pentru a denumi categoria celor care nu simt (qui n’éprouvent pas, p. 219, și nu, cum se spune în textul românesc, care nu arată (problema nu este dacă ei arată sau nu) „nici rușine, nici mîndrie" (p. 219). Cei fără ruşine, spune textul românesc: ne putem întreba dacă nu ar fi fost mai potrivit, tot bazîndu-se pe compunerea prin liniuță, un termen precum cei-fără-de-rușine, care ar fi putut eventual constitui un concept.

Dispersînd-o pe o întreagă gamă de perifraze, versiunea românească renunță astfel să reconstituie grila terminologică de bază, centrată pe ruşine - cel care suferă de pe urma acestei traume: perifraza în sine ar putea fi la limită acceptată, ca în cazul de mai sus, dar cu condiția să se stabilizeze într-o singură formulă şi nu să se distribuie pe o gamă atît de largă de sinonime, care, de cele mai multe ori, introduc nuanțe subiective, contradictorii pentru tipul de context din care fac parte. Ar fi putut recurge, neutru, și la suferindul de rușine, în lipsa curajului de a utiliza ruşinatul, însă fără nici o altă variație, evitînd structuri ce introduc sugestii impresioniste precum cel apăsat de ruşine, omul plin de ruşine, omul tulburat de ruşine, ca să nu mai vorbim de registrul colocvial și mefient al lui cel care crede că are probleme cu ruşinea. Cît privește formula, foarte des folosită, omul (apăsat, tulburat, care suferă etc. de ruşine) ea este cel puțin neîndemînatecă: deși substantiv colectiv, substantivul nu include lesne ambele sexe.

\section{Introducere}

Le honteux

omul căruia îi este ruşine

Un souvenir d'enfance // $O$ amintire din copilärie

nous les honteux

noi, rușinoșii

Sortir de la honte comme on sort d'un terrier // Să ieșim din ruşine ca dintr-o vizuină

le honteux

le honteux préfère

omul care se rușinează

cel apăsat de rușine preferă 
Le détracteur intime // Detractorul intim

un honteux

le honteux

le honteux

le honteux

le honteux

le honteux

un honteux

le honteux

des honteux un individ, suferind de rușine

omul căruia îi este ruşine

omul care suferă de rușine

individul bolnav de rușine

cel apăsat de ruşine

subiectul suferind de rușine

celui căruia îi este rușine

cel apăsat de rușine

oameni plini de rușine

Transparence du honteux // Transparența celui care suferă de ruşine
le honteux
omul care suferă de rușine
le honteux préfère
individul plin de rușine
le honteux
cel suferind de ruşine

La réussite, un masque de la honte // Reuşita, o mască a rușinii

le honteux

individul care suferă de rușine

Leurre de vérité // Momeala adevărului
le honteux
individul care suferă de rușine
le honteux
cel bolnav de rușine
le honteux
omul tulburat de rușine
le honteux
omul apăsat de rușine

Plus le malheur est grand, plus la victoire est glorieuse // Cu cît nefericirea este mai mare, cu-atît victoria este mai glorioasă
chez les honteux
la cei apăsați de rușine
certains honteux
unii $[\ldots]$ cărora le este rușine

Le „je” n'existe quiauprès d'un autre // „Eul” nu există decît în raport cu un altul
le honteux
cel care suferă de rușine
le honteux
cel apăsat de acest sentiment

Un monde où tout fait honte // O lume în care orice stîrnește rușinea

le honteux
le honteux

Honte ou culpabilité? // Ruşine sau vinovăție?

un honteux

le honteux individul plin de rușine

oamenii care suferă de rușine

cineva suferind de rușine

individul care suferă de rușine

Lilliput, star de la honte // Liliputanul, vedeta ruşinii
le honteux
celui suferind de rușine
le honteux
cel afectat de rușine

Tout le monde participe à la honte // Toată lumea ia parte la ruşine

le honteux

indivizii suferind de ruşine

le honteux cel apăsat de rușine

On ne s'attache pas au plus gentil ou au plus diplômé, on s'attache à ceux qui nous sécurisent // Nu ne 
ataşăm de cel mai amabil sau mai diplomat, ne ataşăm de cei care ne securizează

le honteux

le petit honteux

le petit honteux cel ruşinos

micuțul suferind de ruşine

copilul afectat de rușine

Effet désocialisant de la souffrance morale // Efectul desocializant al suferinței morale

du honteux

subiectului apăsat de rușine

le honteux

cel suferind de rușine

Qui suis-je pour l'autre? // Cine sînt eu pentru celălalt?

le honteux

cel apăsat de rușine

le honteux

cel suferind de rușine

Nègres, zoos et hôpitaux psychiatriques // Negri, grădini zoologice și spitale psibiatrice

le honteux individul apăsat de ruşine

\section{Le couple, atome de société // Cuplul, atomul societății}

le honteux se persuade

il pense qu'il est honteux

que le honteux donne à celui qui le re-

garde

\section{Le pouvoir des chaussettes // Puterea ciorapilor}

le honteux

le honteux cel care suferă de ruşine se va convinge crede că are probleme cu rușinea pe care individul suferind de rușine o dăruiește celui care îl privește

individul apăsat de rușine

omul ruşinat

Diseminîndu-se, risipindu-se astfel în traducere, seria semantică honte - honteux - le honteux - éhonté ce desemnează, în fond, o traumă, mereu aceeași, și pe cel traumatizat, denumit însă prin diverse formule mai mult sau mai puțin perifrastice, subminează rețeaua semantică de bază, care pare că șchiopătează constant în căutarea propriei denumiri: or, nu aceasta este structura textului original, care nu manifestă nici o clipă vreo nesiguranță terminologică şi nici nu-și propune să descrie traseul de elaborare a unor concepte. Dacă în traducerea textului literar, această tehnică de traducere poate sfîrși în distrugerea simbolicii textului sursă, care devine invizibilă, mascată de dispersarea lexicală, sau, în orice caz, ilustrează o estetică străină de a aceluia (Berman, 1999, p. 391, 393), în cazul textului specializat, ea nu induce cititorului în nici un caz admirația pentru măiestria lexical-creativă a traducătorului, ci sentimentul că participă la eșecul unui cercetător incapabil de a-și sprijini discursul pe o armătură conceptuală solidă, bîjbîind nesigur printre peri- și parafraze.

\section{Bibliografie}

Almonte, C. (2011). Comentario de libros: Morirse de vergüenza, în „Psiquiatría universitaria”, p. 387-388, [online].

Berman, A. (1999). La traduction et la lettre ou l'auberge du lointain, Seuil, Paris.

Bourguignon, A., Cotet, P., Laplanche, J. \& Robert, F. (1989). Traduire Freud, PUF Paris.

Cassin, B. (éd.) (2004). Vocabulaire européen desphilosophies. Dictionnaire des intraduisibles, Éditions du Seuil/Le Robert, Paris.

Cleynen-Serghiev, E. (2003). „Les Belles Infidèles” en Roumanie. Les traductions des auvres françaises durant l'entre-deux-guerres (1919-1939), Presses Universitaires de Valenciennes, Valenciennes.

Cornea, P. (1972). Ce ne dezvăluie traducerile de la sfîrșitul sec. al XVIII-lea și începutul secolului al XIXlea, în Originile romantismului românesc, Minerva, București.

Crașoveanu, D. (2002). Categorii sintactice necircumstanțiale, Editura Mirton, Timișoara.

Cyrulnik, B. (2010a). Mourir de dire. La Honte, Odile Jacob, Paris.

Cyrulnik, B. (2010b). J’ai connu la honte, interviu de Émilie Lanez, în „Le Point”, 2 sept., [online].

Cyrulnik, B. (2011a). Scham. Im Bann des Schweigens - Wenn die Seele vergiftet, trad. Maria Buchwald și Andrea Alvermann, Präsenz Kunst und Buch Verlag, Hünfelden. 
Cyrulnik, B. (2011b). Morirse de vergüenza. El miedo a la mirada del otro, trad. Maria Pons Irazazábal, Editura Debate, Barcelona.

Cyrulnik, B. (2012). Mai bine mor decât să spun. Ruşinea, trad. Valentin Protopopescu, Editura Trei, București.

Cyrulnik, B. (2013). J'ai surmonté la honte, ce poison de l'àme, interviu de Isabelle Vial, în „Pèlerin”, nr. 6673, 16 iul., [online].

Eliade, P. (2000). Influența franceză asupra spiritului public în România. Originile, trad. Aurora Dumitrașcu, Humanitas, București.

Freud, S. (1900). Die Traumdeutung, în Studienausgabe, S. Fischer Verlag, Frankfurt am Main.

Freud, S. (1909). Analyse der Phobie eines fünfjährigen Knaben, în Studeineausgabe, vol. 8, S. Fischer Verlag, Frankfurt am Main. Freud, S. (2010a). Opere esențiale. Interpretarea viselor, vol. 2, trad. Roxana Melnicu, Editura Trei, București.

Freud, S. (2010b). Micul Hans. Analiza fobiei unui băiețel de cinci ani, în Opere esențiale. Nevroza la copil, vol. 8, trad. Rodica Matei și Ruxandra Hosu, Editura Trei, București.

Gehring, P. (2011). Eine Art innere Gefangenschaft, în „Frankfurter Allgemeine Zeitung”, 5 oct., [online].

Graur, Al. (1973). Gramatica azi, Editura Academiei, București.

Ionescu, G. (1981). Cîteva repere, în Orizontul traducerii, Univers, București.

Janin, Cl. (2003). Pour une théorie psychanalytique de la honte (honte originaire, honte des origines, origines de la honte), în „Revue française de psychanalyse”, vol. 67, nr. 5, p. 1657-1742, Crossref.

Kinston, W. (1983). A theoretical context of shame, în „International Journal of Psycho-Analysis”, nr. 64, p. $213-226$.

Ladmiral, J.-R. (1989). Pour une philosophie de la traduction, în „Revue de métaphysique et de morale. La traduction philosophique", nr. 1, Éditions Armand Colin, Paris.

Ladmiral, J.-R. (1994). Traduire: théorèmes pour la traduction, Éditions Gallimard, Paris.

Ladmiral, J.-R. (1998). Principes philosophiques de la traduction, în Encyclopédie philosophique universelle, ediție coordonată de André Jacob, vol. IV, PUF, Paris.

Popovici, D. (1977). Studii literare. III, Dacia, Cluj-Napoca.

Reiss, K. (2002). La critique des traductions, ses possibilités et ses limites, trad. Catherine Boquet, Artois Presses Université.

Ricœur, P. (2005). Despre traducere, trad. și studiu introductiv de Magda Jeanrenaud, postfață de Domenico Jervolino, Polirom, Iași.

Rosenblum, R. (2000). Peut-on mourir de dire? Sarah Kofman, Primo Levi, în „Revue française de psychanalyse”, LXIV, nr. 64, Crossref.

Semprun, J. (1994). L'écriture ou la vie, Gallimard, Paris.

Tristán, R.M. (2011). Claves para nómorirse de vergüenza, în „El Mundo”, 13 nov., [online]. 